\title{
PH.D.-AFHANDLING OM MYŌSHINJI
}

Ved et offentligt forsvar for afhandlingen Myōshinji. Agency, Institution and Religious Practice in a Contemporary Japanese Rinzai Zen Sect, indleveret til bedømmelse ved Det Teologiske Fakultet, Aarhus Universitet, erhvervede Jørn Borup ph.d.-graden samme sted d. 20. december 2002. Bedømmelsesudvalget bestod af formand, lektor Jeppe Sinding Jensen (Ärhus), professor Michael Pye, Philipps-Universität (Marburg) samt professor George J. Tanabe Jr., University of Hawaii (Manoa). Nedenfor bringes en oversat og redigeret udgave af Jørn Borups indledning og resumé ved forsvaret fulgt af en redigeret udgave af George J. Tanabe Jr.s replik ved samme lejlighed.

\section{Indledning og resumé ved Jørn Borup}

"Er du dybest set ikke bare en turist?", spurgte en rinzai zen-mester (shike) mig engang, da jeg interviewede ham om forskellige ting vedrørende hans liv. En så udtalt mistænkeliggørelse af, hvad jeg i det mindste selv betragtede som en plausibel, akademisk metode, er naturligvis ikke ny. At studere levende religion ved at inddrage andet og mere end klassiske og 'rigtige' tekster anses ofte som helligbrøde ikke blot på universitære institutioner, men også hos skolastisk sindede buddhister. De fleste feltarbejdere inden for buddhismen vil på et eller andet tidspunkt blive dirigeret hen mod helligteksterne, for der står sandhederne. Eller de vil blive præsenteret for meditationsmesteren, der kan belære dem om den krystalklare dharma, udpege månens illuminerende kvalitet eller spejlets selvindlysende refleksion - for kun praksis, siges det, giver indsigt.

At der mildest talt kun forekommer få eksempler på feltarbejde og generel interesse $\mathrm{i}$ nutidig japansk zen-buddhisme som en levende religion kan synes paradoksalt. Den traditionelle zen-buddhisme har i hele Østasien og Japan en lang historie med en betydelig række tekster, traditioner, institutioner, ideer, praksisser og levende mennesker. Den har en lang forskningstradition i både Kina, Japan og Vesten. Indtil for to årtier siden var den karismatiske D.T. Suzuki, og den 'Suzuki-effekt' han skabte, institutionen, gennem hvilken zen blev studeret og brugt $\mathrm{i}$ Vesten - og i visse traditioner stadig studeres og bruges. Suzuki-zen er subtil, men også reduktionistisk. Den idealiserer normativt og fravælger de elementer, der ikke passer ind i den idealiserede diskurs. Måske er Suzuki-zen den vigtigste grund til, at der indtil for nylig næsten ikke har eksisteret kilder på vestlige sprog om moderne japansk zen. Den dag i dag findes der kun sporadisk og sparsom information om rinzai-sekten, ikke mindst i forhold til deres praksis, og selv på japansk er næsten alle akademiske publikationer af historisk, doktrinær eller filologisk art. Disse er værdifulde, men utilstrækkelige, hvis man vil vide noget om, hvordan mennesker i virkeligheden bruger og forstår zen-buddhismen. 
Post-Suzuki-zen har åbnet op for nye metoder og nye empiriske forskningsvinkler. Efter lidt 'zen-shopping' valgte jeg Myōshinji som empirisk afgrænset område. Myōshinji er den største af de japanske rinzai-sekter både med hensyn til antallet af medlemmer og antallet af templer og desuden med flest (nutidige) kildetekster. Myōshinji ejer et universitet og to vigtige zen-forskningsinstitutioner og er vel repræsenteret i Kyoto, hvor jeg af forskellige grunde valgte at udføre det meste af mit feltarbejde. Selv om jeg blev advaret mod at beskæftige mig med en så gammel, traditionel og tilsyneladende 'tung' institution som Myōshinji (det er ikke for ingenting, at munkeklostret på hovedcentret kaldes “djævlehallen”), udviklede forskningsprocessen sig relativt gnidningsfrit, takket være hjælpsom og venlig assistance og endda oprigtig interesse i et projekt, som absolut ikke alle fandt mistænkeligt eller udtryk for skjult turisme.

Mit projekt var hverken ment som et nyt forskningsparadigme eller en ny skolastisk 'drejning af dharma-hjulet'. Afhandlingen er produktet af en undersøgelse af et endnu ikke undersøgt empirisk område inden for studiet af zen, buddhisme og japansk religion. Som sådan kan man sige, at afhandlingens største fortjeneste beror på at studere zen som en almindelig religion.

Min overordnede interesse var at undersøge det tilsyneladende paradoks mellem en traditionel, streng, elitær religion og en lægfolksreligiøsitet. Med andre ord, hvordan forholder buddha-natur sig til forfædre, munke til bedstemødre, tekster til praksis, idealer til realiteter, individer til institution?

Det introducerende kapitel et (Introduction) omhandler generelle refleksioner over teori og metode. Jeg kontekstualiserer den (zen-)buddhistiske forskningshistorie og dens videns-sociologiske rammer. Jeg definerer og forklarer min forståelse og brug af begreberne religion, buddhisme og zen, og jeg diskuterer korrelationerne mellem ritualer, tekster, aktører og religiøs praksis. I det sidste afsnit om "unity and diversity" diskuterer jeg begreber som 'Stor' og 'Lille Tradition', folk, elite, popular, practical og common religion. Jeg argumenterer for relevansen af at se religiøse samfund inden for både såkaldt todelte og 'holistiske' modeller, dvs. både som stratificerede lag og inden for det samme 'totale felt'.

Jeg argumenterer også for metodologisk pluralisme. Dette forsøger jeg både ved at brolægge tidligere faglige skyttegrave og ved at inkludere forskellige kilder og materialer. Projektets empiriske data indeholder således manualer, lærebøger, tidsskrifter, brochurer, forskningsrapporter, den officielle sekt-konstitution, institutionens såvel som mine egne interview-undersøgelser samt (deltagende) observation af mange forskellige slags ritualer og religiøs praksis.

Kapitel to (Myōshinji: Institution, history and structure) beskriver henholdsvis Myōshinji-sektens legendariske og 'virkelige' historie. Jeg beskriver begreber som tradition, lineage og transmission og fortolker disse som legitimerende begreber for et helligt slægtskab. Historien gennemgås fra sektens grundlæggelse i det fjortende århundrede, over den tidlige middelalder og Tokugawa-periodens politiske og institutionelle tempel- og husholdsstrukturer. Den vigtige Meiji-tid får en speciel fokus med 
røster fra Myōshinji, zen og buddhistiske kredse, specielt med henblik på reaktionen på 'overgangsperioden til moderniteten'. Udviklingen fra efterkrigs- til nutidig Myōshinjizen er beskrevet med vægt på såvel juridiske, institutionelle, økonomiske og semantiske aspekter som fokus på social, læg-orienteret og international zen.

Kapitel tre (Agents) beskriver og diskuterer de forskellige typer af aktører inden for Myōshinji-institutionen. Jeg bruger emic-begreberne shukke ('en, der forlader hjemmet', dvs. munk) og zaike ('husstand', dvs. lægmand) som hovedkategorier til at diskutere idealer og realiteter for forskellige underordnede institutionelle roller og typer af aktører. Shukke er stadig idealet for Myōshinji (og alle zen-sekter i Japan). Zaike indeholder de hengivne troende (shinto), 'sandheds-søgerne' (kyüdō gumi), medlemmerne (kaiin), de 'periodiske buddhister', de traditionsbundne familier (danka), de religiøse grupper (confraternities), og hvad jeg kalder "mixed categories" bestående af intellektuelle og udlændinge.

Kapitel fire (Place) var oprindelig ment som et kort afsnit eller et referencefelt til fodnoterne. Da fodnoterne blev for mange, og da afsnittet ikke syntes at have en logisk placering, udviklede det sig til et individuelt afsnit. Dette tager nogle af de teoretiske diskussioner fra introduktionen op og placerer dem i en japansk, buddhistisk og zenkontekst.

Kapitlerne to, tre og fire var individuelle beskrivelser og diskussioner af vigtige aspekter, men også nødvendige forudsætninger for det femte og længste kapitel (Religious practice). Kapitlet indeholder flere afsnit, der teoretisk diskuterer klassifikation samt vigtige begreber og fænomener relateret til religiøs praksis, f.eks. transempiriske verdener, kulturelle værdier, tro og rituel formalitet. Kapitlet inkluderer forskellige afsnit om både klerikal og lægorienteret rituel praksis, klosterliv, daglige, kalender- og overgangsritualer, koan-praksis, tiggergang, tekster, meditation og 'folkezen'.

'Opdragelse' eller 'udbredelse af læren' $(k y \bar{o} k a)$ er et ideal om at gøre præster til bedre præster og lægmedlemmer til bedre lægmedlemmer ved hjælp af offentligt tilgængelige tekster og forskellige religiøse arrangementer. Jeg diskuterer kyōka som en slags individuel religiøs praksis, men også som en hermeneutisk og institutionel strategi ideelt underliggende al praksis. I den forstand har al religiøs praksis et normativt ideal, som når kulturelle værdier (f.eks. harmoni), overgangsritualer (f.eks. død), 'common rituals' (som f.eks. obon) eller det daglige liv er 'helliggjort' og 'buddhiceret' i publikationer fra hovedcentret.

Analyser af spørgeskemaer og observation af religiøs praksis viser dog, at sådanne idealer langt fra korresponderer med virkeligheden for Myōshinjis medlemmer. Mange præster læser og distribuerer ikke institutionens publikationer. De afholder ikke så mange religiøse forsamlinger og mediterer ikke så meget, som de ifølge idealerne burde. Folk er ikke interesseret i de institutionelt mere 'fortættede' ritualer (f.eks. meditation eller mindeceremonier for zen-patriarkerne), men er langt mere engagerede i sociale forsamlinger og 'common rituals' (f.eks. obon og nytår). Selv om institutionen prøver at polere sit image, så er ritualer relateret til døden (kremation og mindehøjtideligheder for 
forfædrene) det, de fleste bruger zen og buddhistiske institutioner til. Mine egne undersøgelser viste imidlertid, at de fleste var bevidste om, at det ikke burde være sådan.

Hovedpunkterne i det konkluderende kapitel diskuterer problemet omkring repræsentation. Kapitlet opsummerer afhandlingen og sammenholder resultaterne og diskussionerne med spørgsmålene om relationerne mellem aktører, institution og religiøs praksis.

Jeg kalder den inklusive strategi med at få alle ombord på det institutionelle fartøj for 'paraply-zen'. Denne er et ideal, der også berøres i generelle toner i legitimationen af zen i et buddhistisk perspektiv, der inkluderer doktrinær argumentation og historisk manifestation.

Paraply-zen integrerer både elitær zen og folke-zen i en symbiotisk Stor Fortcelling, $i$ hvilken institutionen som en dynamisk organisation anerkender forskellige kilder som aspekter af ét stort reservoir.

Specielt siden Meiji-renæssancen og som en kontinuerligt fremadskridende udvikling, er elitens indflydelse blevet begrænset. Kleresiet har mistet symbolsk magt, den Store Tradition er blevet udsat for en generel demokratiserings- og humaniseringsproces og er ikke mere så stor. Zen er også kommet til masserne. Institutionens 'opdragelsesstrategi' har til formål at spiritualisere medlemmerne som udtrykt ved promotionen af sloganet "samme tro, samme praksis" (dōshin dōgyō). Kyōka Sentā, et center for religiøs opdragelse, og lægorganisationen Hanazonokai såvel som meditationsgrupper for lægfolk illustrerer sådanne ligestillingsbestræbelser.

Hierarkisk eller 'ren' zen er et andet perspektiv og en anden strategi fra Myōshinjiinstitutionen. I hele (zen-)buddhismens historie har også en elitær diskurs været promoveret til at tingsliggøre forskelle mellem ren og uren buddhisme og zen. Munke, shukke, og den Store Tradition har ofte været buddhismens 'default value' som den hierarkisk overordnede del, essentielt forskellig fra læg-zen, folke-zen og de lokale små traditioner. Sådanne stratifikationer holdes i live ikke bare ved kontinuerligt at promovere begreber (shukke, satori), symboler (genealogier, titler, rang) og rituelle praksisser (meditation, tiggergang) som kleresiets symbolske kapital. De bliver også 'udført' rituelt i templer, hvor hierarkier og essentiel distinktion bliver understreget, som når munke går tiggergang eller præster og mestre indvies. Rituel identifikation mellem læg, munk og Buddha (f.eks. forskriftceremonier, meditation og dødsritualer) er midler til symbolsk at overskride og udfordre grænser. Men de understreger også den ideelle, rene zens symbolske magt og bekræfter den institutionelle stadfæstelse af essentiel forskel.

Ingen af disse positioner eller perspektiver er absolutte. Begge strategier bliver brugt, afhængig af kontekst - nogle gange også inden for samme diskurs eller samme ritual, som eksemplificeret ved ritualet på Empukuji med cirkumambulation om toiletterne. Institutionen må balancere mellem begge perspektiver i en dynamisk dobbeltposition.

Dette skyldes, at især i moderne tid er lægreligiøsitet og Små Traditioner ikke reduceret til passive modtagere. Også lægaktører er aktive aktører, som den Store Tradition i vidt omfang er afhængig af. Lægfolket kan selv udøve magt på forskellig vis, den mest 
alvorlige ved at negligere den religiøse institution ved f.eks. at flytte til storbyen eller have begravelsesindustrien til helt at overtage de religiøse og rituelle foranstaltninger forbundet med døden.

Desuden har lægbuddhister og Små Traditioner forskellige interesser i at relatere sig til både paraply-zen og hierarkisk zen. De mere intellektuelle og elitære læg-zenbuddhister har interesse i at deltage i praksisser og diskurser inden for den 'rene zen' som D.T. Suzuki og Shin'ichi Hisamatsu samt læg-organisationer som FAS Society. Disse, samt en del zazenkai-(meditationsgruppe-)deltagere med højt engagement $\mathrm{i}$ både doktrinære studier og forskellige former for religiøs praksis, udgør en minoritet, men er alligevel vigtige repræsentanter for moderne japansk zen.

På den anden side er en ret stor gruppe lægmedlemmer også interesseret $\mathrm{i}$ at forblive, hvad de er som enten hengivne troende eller passive tilhørere. Spørgeskemaundersøgelser og observationer viste, at mange faktisk føler sig vel tilpas med rollerne som de 'lavere dele' i en hierarkisk relation med de religiøse specialister og den Store Tradition. Og mange syntes at have det godt med at flyde rundt i en paraply-zen institution, hvor deres egen religiøsitet er legitimeret, næsten uanset hvad de gør eller tror.

Zen-traditionen og Myōshinji-institutionen har mange idealer, der bruges til at definere en 'ren zen' og Stor Fortælling. Men meget få individer synes i virkeligheden fuldt ud at integrere sådanne sammenhængende store fortællinger i deres bevidsthed og $\mathrm{i}$ deres religiøse praksis. Interviews og observationer - og endda også normative tekster fra institutionen, der legitimerer dette træk - viser, at både individer og f.eks. paraplyzen orienterer sig meget mere bredt og udefinerbart.

Afhængigt af kontekst er nogle ideer og praksisser mere fastlåste end andre. F.eks. er ceremonier på hovedcentret mere formaliserede end de lokale. Semantisk fortættede tekster og ritualer (som f.eks. hjertesutraen og meditation) er åbne for mange mulige fortolkninger og funktioner, som jeg også viser i afhandlingen. Det samme har forskriftceremonien, pilgrimsfærd, koan-studier, tiggergang, lokale folkelige festivaler og ritualer relateret til døden. Og det har begreber og idealer som oplysning, fortjeneste og harmoni.

Paraply-zen må indeholde mange forskellige, enkelte historier og praksisser inden for - eller i det mindste ikke for åbenlyst i strid med - de store fortællinger fra den rene, hierarkiske zen. På den baggrund er det nødvendigt $\mathrm{i}$ det mindste at se det unikke ved zen i et andet perspektiv. På den anden side er demytologiseret, almindelig og levende zen bestemt ikke mindre interessant eller unik. 
Replik ved George J. Tanabe Jr.

Religiøse fænomener er komplekse, men i de fleste studier fokuseres der kun på en del af helheden. Denne afhandling forsøger at omfatte alle vigtige aspekter af Myōshinji, og det er forfriskende at læse et studium, der væver særskilte tråde sammen til et større billede. Myōshinji drøftes som en moderne størrelse, der omfatter klerikale og lægaktører, institutionelle strukturer og religiøs praksis.

Kapitel 1 (Introduction) introducerer afhandlingens grundlæggende formål: "at undersøge en nutidig zen-buddhistisk sekt med fokus på, hvad jeg ser som vigtige 'levende' aspekter af religionen; aktører, institution og religiøs praksis” (s. 1). Borup lægger sin afhandling i forlængelse af tidligere zen-studier og fremhæver, at han ønsker at undgå ensidige eller reduktionistiske tilgange. Han tilslutter sig en 'metodologisk agnosticisme', som imidlertid ikke får ham til at begrænse sig til bestemte tilgange. Han er åben for inddragelse af forskellige metoder. I overensstemmelse med denne vidtfavnende tilgang undgår Borup at forskrive sig til en metode, der vil isolere Myōshinji fra 'virkeligheder', som ikke er indbefattet af metoden. Hans insisteren på at se templet inden for et spind af relationer modsvarer hans definition af religion som et kulturelt felt, i hvilket aktører og institution handler i relation til sete og usete verdener. Doktriner, ritualer, tekster, forskellige praksis, Store og Små traditioner, abstraktioner og handlinger indgår alle i studiet.

I kapitel 2 (Myōshinji: Institution, history and structure) efterspores Myōshinjis legendariske og virkelige historier. Samtidig undersøges de åndelige, institutionelle og personlige slægtskaber, som definerer templet og sekten. Borup ser på de vigtige relationer mellem Myōshinji og regering fra middelalder til moderne tid. Moderne Myōshinji er lovformeligt konstitueret, har udviklet zen for både læg og internationalt publikum og ernærer sig økonomisk primært af indkomster knyttet til tjenester relateret til døden.

I kapitel 3 (Agents) undersøges kleresiet og lægfolket. Præster (shukke) drager hjemmefra, men vender tilbage for at gifte sig og stifte familie. Der eksisterer konflikter mellem husholderens afholdenhed og livsudfoldelse, mellem den fulde ordination og lægpræstens status, tilkendt gennem ango-e. Præster lever inden for et netværk af hierarkier og statuser, der spænder fra den rituelle specialist til almindelige medlemmer af menigheden. Borup undersøger tempelhustruernes vigtige, men ofte oversete rolle som ægtefæller, mødre, assistenter og endog præster. Nonner og sønner drøftes kort. Lægstanden består af formelle medlemmer og af periodiske 'klienter'. Borup diskuterer også terminologien og kategorierne for religiøse grupper (confraternities) og dannede intellektuelle. Kapitlet slutter med en kort beskrivelse af udenlandske zenudøvere.

En af afhandlingens styrker er dens dækning af aktører som en måde at anskue den 'levende' Myōshinji på. Borup udviser forsigtighed, når han diskutere den terminologi, der definerer de forskellige aktører. Hans drøftelse har imidlertid en tendens til at definere disse termer som kategorier i stedet for virkelige mennesker. Selve ordet 'aktør' (agent) er noget upersonligt. Fx dækker hans diskussion af religiøse grupper (confraternities) de forskellige termer for denne slags organisation. Hans beskrivelse af 
deres inter-, trans- og ikke-sekteriske natur er meget interessant. Da han har lavet feltarbejde, kunne Borup have inddraget en righoldig etnografisk viden, men han nøjes i stedet med at referere til en præst og forskellige kvinder, han talte med. Hans informanter fremstår som kategorier og ikke som virkelige folk. Han diskuterer præster, hustruer, nonner og sønner, men næsten ingen af dem bærer rigtige navne eller har personligheder og oplevelser. Borups introducerende kommentarer om vigtigheden af aktører skabte en forventning om, at hans afhandling ville undgå de traditionelle depersonaliseringer inden for akademiske studier og være fyldt med faktiske individer. På trods af hans åbenhed over for forskelligartet metodologi formår han ikke at bruge etnologien til at skildre virkelige individer $i$ hans studie. Han udnytter således ikke chancen for at studere mennesker og aktører.

Det er urimeligt at kritisere et arbejde for ting, som det ikke intenderer, og etnografisk viden er muligvis ikke en del af afhandlingens forehavende. Mit første spørgsmål til Borup er derfor: 'Bruges begrebet 'aktører' for at udelukke virkelige mennesker, det vil sige, er det tænkt at skulle fungere som en kategori eller rolletypologi (præster, nonner, sønner etc.)? Er udelukkelsen af virkelige individer metodologisk bevidst, og i givet fald, hvorfor?"

I kapitel 4 (Place) fortsættes undersøgelsen, nu med henblik på sted, på en i forhold til den karakteristiske tilgang til diskussion af begreber og kategorier genkendelig måde. Efter at have introduceret Alan Grapards tre kategorier for helligt rum, diskuterer Borup zentemplet som et helligt område, der rummer symbolske betydninger. Diskussionen af sted og arkitektur er holdt på et generelt plan, og ligesom drøftelsen af aktører er depersonaliseret, er undersøgelsen af sted ikke specielt fokuseret på Myōshinji. Jeg formoder, at Myōshinji modsvarer det generelle mønster, fx de syv haller, men så får vi at vide, at hovedtemplet i Kyoto er atypisk (s. 126). En forklaring på, hvorfor hovedtemplets størrelse, historie og symbolske vigtighed er atypisk, kunne bidrage til en forståelse af Myōshinji selv. Igen lærer vi meget om zentemplers generelle mønstre, men kun lidt om Myōshinjis særegenhed som et bestemt sted.

Mit andet spørgsmål er dette: "På hvilke punkter modsvarer Myōshinji zentemplernes generelle mønstre, og på hvilke punkter er de forskellige?” Mit tredje spørgsmål har at gøre med repræsentation, som diskuteres side 20: "Repræsenterer det hellige steds symbolske betydning Myōshinji-munkenes og -nonnernes forståelse, og i givet fald, hvilke vidnesbyrd er der? Hvis der ikke er nogen vidnesbyrd for at koble disse betydninger specifikt til Myōshinji, hvis betydninger er de da?"

Kapitel 5 (Religious practice). Borup begynder med en diskussion om tro - på en selv eller buddha-naturen i en selv. Han gør opmærksom på den udbredte opfattelse, at genze riyaku ikke er rigtig zen. Hans diskussion af kudoku, dōtoku og gō er oplysende, specielt iagttagelsen af, at mens kudoku og dotoku er velkendt, er der en overraskende tavshed omkring karma, måske på grund af dets negative aspekt som årsag til dårlige ting. Hans diskussion af konfucianisme og pligt som sociale værdier sammenvævet med buddhistiske begreber er også fremragende. En række termer og begreber defineres og 
diskuteres: shinkō (både kognitiv og affektiv), shinjin, shōjin, anjin, gishiki, girei, shugyō, gyōji, zazen etc.

Mens drøftelsen af uddannelse ( $k y \bar{o} k a, f u k y \overline{)})$ bevæger sig i retning af religiøs aktivitet i stedet for praksis, kommer denne del-specielt afsnittet om skoler og træning af præster og hustruer - tæt på at skildre virkelige menneskers liv. Borup drager nytte af undersøgelser, som viser virkelige (i stedet for kategoriske) præsters faktiske holdninger, og undgår derved en mere generel behandling af emnet gennem definition af termer og kategorier. Hans diskussion om Hanazonokai er fremragende, fordi den bevæger sig ind på faktiske aktiviteter. Jeg ønskede selv at få yderligere information om andre grupper som Million People Sutra Copying Assembly, Musō Kyōkai og Okagesama Undō. De lyder vældig interessante, og deres aktiviteter, som goeika, fortjener indgående studier. Forsøg på internationalisering som en del af indenrigspolitikken samt transformationen af zen til en livslang religion er meget fascinerende områder, og det ville være værdifuldt at vide mere om disse. Til trods for denne mangel på fuldkomne data hører denne sektion til en af afhandlingens bedste.

Styrken i denne del er at påpege problemet omkring depersonalisering i skildringen af aktører. Problemet er måske også en konsekvens af at overtage en så bredtfavnende tilgang, som er vidunderlig, men prisen er en vis grad af overfladiskhed i drøftelsen. Meget $i$ denne afhandling består af typologi-, kategori- og grundtrækdiskussioner. Disse er alle nyttige, men noget abstrakte i forhold til de 'levende' realiteter, han søger at indfange. Når Borup imidlertid bryder ud af sin 'kategoriske fremstillingsform' og præsenterer os for etnografisk viden, bliver aktørerne levende som ægte mennesker eller menneskegrupper.

Afsnittet om monastisk praksis er godt, men forklaringerne bygger nogle gange på Dōgens eller Hakuins eller Bernard Faures tekster. Når Borup fx læner sig op ad Faure for at forklare, at koan er en slags dharani, som ikke kun skal forstås intellektuelt eller afkodes metaforisk, men mediteres over og kropsliggøres gennem forskellige aktiviteter, skal vi så antage, at det også er Myōshinji-munkenes forståelse (s. 186)? Her dukker atter spørgsmålet om repræsentation op. Der er andre steder, hvor Borup læner sig op ad ikke-Myōshinji-kilder som forklaringer. Og igen må jeg spørge: "Hvilken garanti eller vidnesbyrd er der for at overbevise os om, at Dōgen, Hakuin, Faure eller andre repræsenterer Myōshinji samfundet?" Myōshinji-munkenes stemmer er selv påfaldende tavse. Det samme gælder diskussionen af takuhatsu, der beskrives gennem sammenligning med theravada-praksis, Catherine Bell, D.T. Suzuki, Caputo, Tambiah, Gernet, Bordieu etc. Det er alt sammen spændende materiale, men repræsenterer det nødvendigvis Myōshinji-munkenes forståelse? Hvad synes de? Skulle de ikke have lov til at repræsentere sig selv? Til andre tider bruger Borup vidnesbyrd, der de facto repræsenterer Myōshinji. Når han på basis af spørgeskemaundersøgelser og interviews finder frem til, at ordination ikke sættes særligt højt (s. 198), er det meget interessant og troværdigt, fordi det repræsenterer munkene selv. Beskrivelsen af Yamakawa Sōgens indsættelse som mester (s. 199-201) og Okada Seihōs rituelle overtagelse af templet 
hviler også på gode vidnesbyrd fra feltarbejde, der direkte fortæller os om Myōshinjipraksis.

Afsnittet om tilbedelse er vigtigt om ikke for andet så af den grund, at der her påpeges vigtigheden af tilbedelse, et område, der stort set er ignoreret af andre forskere. Borup diskuterer på et tidligere tidspunkt elementer og teoretiske aspekter ved ritualer, og denne diskussion rejser spørgsmålet om tilbedelsens definition og dynamik: "Hvad er forskellen mellem tilbedelse og ritual? Hvordan forstås guddomme, hvilken rolle spiller de i de to handlingstyper?"

Borups diskussion af realiseringsritualer, specielt meditation, er yderst interessant, fordi han påpeger, at meditation ofte praktiseres som et ritual uden realisering som mål (s. 230). Virksomheder bruger ofte meditation for at indprente en underdanig holdning hos de ansatte. Meditation anvendes også for at opnå psykisk velvære frem for som frelsesmiddel (s. 233). Men der er også sandhedssøgerne, som praktiserer meditation som et realiseringsritual. Diskussionen af meditationens mangeartede betydninger er $i$ høj grad betydningsfuld.

Undersøgelsen af lokal folkezen-festivaler er yderst fremragende og er afhandlingens bedste del. Den omhandler bestemte begivenheder, virkelige mennesker, virkelige steder, og viser interrelationen mellem zen og folkepraksis. Den rummer også fascinerende exotica som cirkumambulationen om toiletterne. Borup præsenterer os for en interessant iagttagelse omkring keisakuen som et meditationsværktøj og en healingspind (s. 258). Afsnittet om lægforeskrifter er også godt. Det indeholder også en anden vigtig diskussion om relationen mellem det at tage imod forskrifterne som et ritual og som etiske leveregler (s. 266f).

Afsnittet om kremationer er også godt, men rejser på ny spørgsmålet om relationen mellem de generelle mønstre inden for buddhistiske og zenkremationer og Myōshinjis begravelsespraksisser. Jeg ud fra, at de er identiske.

I Borups konkluderende kapitel gentages hans bredtfavnende tilgang antydet gennem hans vidunderlige term paraply-zen (umbrella Zen). Ritualer er 'mangfoldige', og han noterer sig de komplekse bevægelser, som på en og samme tid bekræfter og overskrider kategorier. Det er et fortræffeligt udsagn om nødvendigheden af og vanskelighederne ved at forsøge at rumme det hele, hvis dele ikke altid passer godt sammen.

Det er en god afhandling, der klart fortjener at blive antaget. Den stærke side ved den bredtfavnende tilgang er, at den giver os en oversigt over Myōshinji i alle dens hoveddele, men det er også dens svaghed. Den lider under en vis grad af overfladiskhed i skildringen. Der er to overlappende linjer. Den første er udlægningen af termer, kategorier og typologier, som omhandler typer i stedet for virkelige mennesker og steder. Den anden er den etnografiske præsentation af virkelige mennesker og steder. Mens jeg beklagede mig over manglerne ved den første og priste den anden for dens fortjenester, er begge vigtige for afhandlingen. Begge linjer er dog ikke altid til stede $\mathrm{i}$ hvert kapitel, og min beklagelse går i virkeligheden på de dele, hvor kategorierne lægges frem uden behørig hensyntagen til de levende etnografiske data. Hvis disse 
afsnit kunne udfyldes på denne måde, ville denne i forvejen gode afhandling blive endnu bedre.

Det andet tilbagevendende problem drejer sig om repræsentation. Opfattelser hos folk uden for Myōshinji kan være meget anvendelige, men Borup må tilføre en eller anden slags garanti, der kan bidrage til at koble generelle mønstre og udenforståendes påstande med Myōshinji-samfundet selv. 